\title{
A measurement scale for assessing intellectual capital disclosure
}

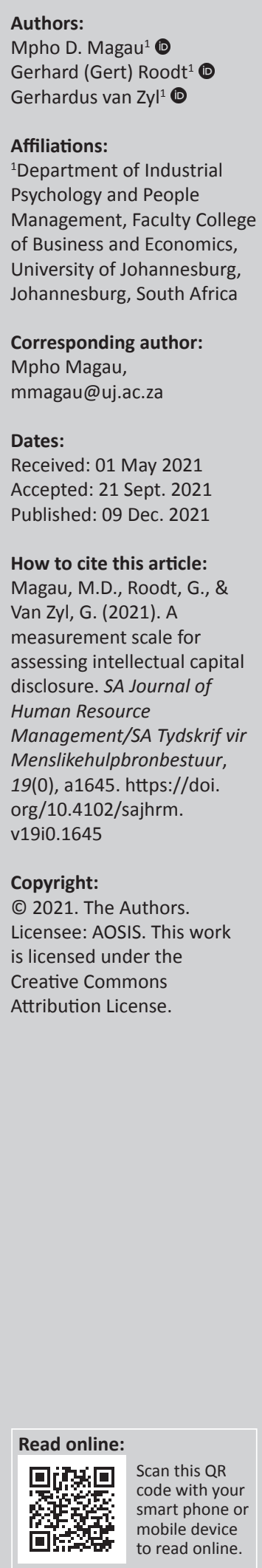

Orientation: Intellectual capital disclosure (ICD) including structural capital (SC), human capital $(\mathrm{HC})$, and relational capital (RC) of non-financial information creates a shareholder value. Conflicting evidence on this voluntary disclosure suggests the need to develop an ICD measurement scale for reducing information asymmetry in the annual financial reporting.

Research purpose: The main aim of this study was to develop a multi-dimensional measurement scale consisting of groups of items for critically examining the extent of ICD in the corporate annual reports or integrated reports to build investor confidence.

Motivation for the study: The lack of voluntary disclosure on intellectual capital (IC) increases information asymmetry and negatively affects investor decision-making. An ICD measurement scale is expected to facilitate the reliable extraction of non-financial information from the annual reports or integrated reports.

Research approach/design and method: A quantitative cross-sectional study was used with an ICD measurement scale for extracting information from 150 annual reports of the Johannesburg Stock Exchange (JSE) listed companies. The measurement scale was subjected to exploratory factor analysis (EFA).

Main findings: The ICD measurement scale yielded one factor structures across all three dimensions with internal reliability statistics (Cronbach alphas) of SC (0.849), HC (0.806) and $\mathrm{RC}(0.749)$, after the second level factor analysis.

Practical/managerial implications: The ICD measurement scale will enable the market participants to understand how non-financial information can be extracted reliably from the annual reports and use to assess the value of intangible assets.

Contribution/value-add: The novel contribution of the study is the construction of a measurement scale for assessing ICD.

Keywords: intellectual capital disclosure; structural capital; human capital; non-financial information; information asymmetry.

\section{Introduction}

Disclosed non-financial information on intellectual capital (IC) which includes structural capital (SC), human capital (HC) and relational capital (RC) is value-relevant in the financial markets. Intellectual capital disclosure (ICD) allows institutional investors to analyse the impact intangible assets have on shareholder value (Abdolmohammadi, 2005; Abeysekera, 2006; Abhayawansa \& Guthrie, 2010, 2014, 2016; Rimmel, Nielsen, \& Yosano, 2009; Vergauwen, Bollen, \& Oirbans, 2007). Although several attempts have been made on assessing ICD, the underlying challenge of consistent measurement can be attributed to the absence of standardised disclosure indexes, which ultimately seem to discourage efforts to quantity the value of non-financial information (García-Meca, Parra, Larrán, \& Martinez, 2005; Guthrie, Petty, \& Ricceri, 2006; Schneider \& Samkin, 2008; Whiting \& Miller, 2008).

Disclosure indexes, also referred to as measurement instruments, are use in IC theory for examining the extent of non-financial information disclosure in annual reports. A disclosure index is defined as:

$[A]$ qualitative based instrument designed to measure a series of items which, when the scores for the items are aggregated, gives a surrogate score indicative of the level of disclosure in the specific context for which the index was devised. (Coy, 1995, p. 121)

Scores derived are normally used to perform quantitative data analysis for predicting the value of ICD towards shareholder value creation despite the conflicting results (Abdolmohammadi, 
2005; García-Meca et al., 2005; Gerpott, Thomas, \& Hoffmann, 2008; Guthrie et al., 2006; Rimmel et al., 2009; Schneider \& Samkin, 2008; Striukova, Unerman, \& Guthrie, 2008; Vandemaele, Vergauwen, \& Smith, 2005; Whiting \& Miller, 2008).

This plethora of research in ICD yields no empirical evidence regarding the measurement of the internal consistency of disclosure indexes at both construct and item level, which led to the construction of a measurement scale for assessing the extent of ICD in corporate annual reports.

\section{Intellectual capital}

Intellectual capital refers to the company's intangible assets which create business value when there is seamless interaction amongst SC, HC and RC (Kannan \& Aulbur, 2004). Structural capital resides within the organisation's architecture and reflects internal knowledge, innovation and structural capabilities that create wealth for shareholders through HC (Anifowose, Rashid, \& Annuar, 2017). According to Chen, Cheng and Hwang (2005), HC collectively refers to people's contribution, skills, knowledge, abilities, motivation and experience which create value for customers. When properly orchestrated, both SC and HC result in optimum customer experience, retention and the overall satisfaction which is about improving RC. Kale, Singh and Perlmutter (2000, p. 218) referred to RC as the level of mutual trust, respect, and friendship that arises out of close interaction at the individual level between alliance partners'. Relational capital is 'the knowledge embedded in the relation to stakeholders and its relevant value' (Hosseini \& Owlia, 2016, p. 736). Compared to the traditional financial measure, IC measures present investors with behavioural-based, structural and relationship-oriented information about the organisation (Litschka, Markom, \& Schunder, 2006). In unlocking the value of IC, Chiucchi and Dumay (2015) highlighted the significance of accounting practices in building an IC measurement system. Hence, any efforts to evaluate ICD must consider a measurement scale with key pivotal points for generating insights from the non-financial information (Gerpott et al., 2008; Guthrie et al., 2006; Oliveira, Rodriques, \& Craig, 2006; Schneider \& Samkin, 2008; Vandemaele et al., 2005). Moreover, investors and the broad investment community need the IC information for determining shareholder value. Hence, a measurement scale of ICD is expected to aid the reliable extraction and use of non-financial information to integrate in the investment process.

\section{Intellectual capital disclosure}

Theoretically, researchers investigate ICD to determine the organisations' reporting patterns and the willingness to share information about their strategy, business models, SC, $\mathrm{HC}$ and RC. ICD, including structural, human and RC information, is insightful for reducing investors' perceptions of risk and increases the companies' capacity to generate funding for their growth or expansion plans.
ICD literature is increasing significantly with more developed countries realising the value-relevance of intangible assets towards the companies' market capitalisation (Abeysekera, 2006; Abdolmohammadi, 2005; Abhayawansa \& Guthrie, 2010, 2014, 2016; Anifowose et al., 2017; Vergauwen et al., 2007). As a result, various regulatory requirements such as the International Financial Reporting Standards (IFRS) and the International Integrated Reporting Framework (IIRF) have implemented measures to improve ICD. Developed countries also continue to make significant strides towards transparency, governance and accountability in ICD.

Specifically, the Integrated Reporting Committee of South Africa (IRCSA) promotes ICD in annual reports through integrated reporting (Atkins \& Maroun, 2015; Setia, Abhayawansa, Joshi, \& Vu Huynh, 2015). Annual reports are a source of ICD used by investors to monitor the business performance of targeted investments. Depending on the extent of ICD, annual reports have the potential to enhance the transparency amongst executives, stakeholders, shareholders and investors. Despite the regulatory requirements on (IR), annual reports are useful for monitoring impression management and creating ideal investor and public perceptions (Edgar, Beck, \& Brennan, 2018). With the absence of the generally-accepted framework for ICD around the world (An \& Davey, 2010) and lack of consensus on standardised corporate reporting (Alfraih, 2018), it is becoming increasingly paramount to investigate a measurement scale to assess a broad range of IC information to be disclosed. Therefore, the conceptual framework depicted in Figure 1, with selected items used in the study, served as a guide for constructing the ICD measurement scale incorporating structural capital disclosure (SCD), human capital disclosure (HCD) and relational capital disclosure (RCD).

The framework posits that the extent of ICD is influenced by both voluntary disclosure of non-financial information and the corporate annual reporting requirements, which ultimately lead to shareholder value creation.

To illustrate, the literature survey provides that SCD concerns the critical assessment of information disclosed regarding intellectual property (IP) that includes goodwill, trademarks, research and development (R\&D), innovation, corporate brand, product development and market intelligence (Arvidsson, 2011; Dominguez, 2011; Lenciu \& Mati , 2014; Piehler, King, Burmann, \& Xiong, 2016; Sonnier, 2008). Another key component of SCD is the companies' transparency about decisions taken on structural choices, business strategy, leadership and group ownership structure (Bini, Dainelli, \& Giunta, 2016; Olson, Slater, \& Hult, 2005; Slack \& Munz, 2016), which can provide useful information to assess board effectiveness. Management philosophy relates to the general thoughts, ethics and moral good in social norms and human actions, which forms part of SCD assessment. This information pertaining to organisational culture, growth and management processes (Gamerschlag, 2013; García-Meca et al., 2005; Rimmel et al., 2009) is useful 


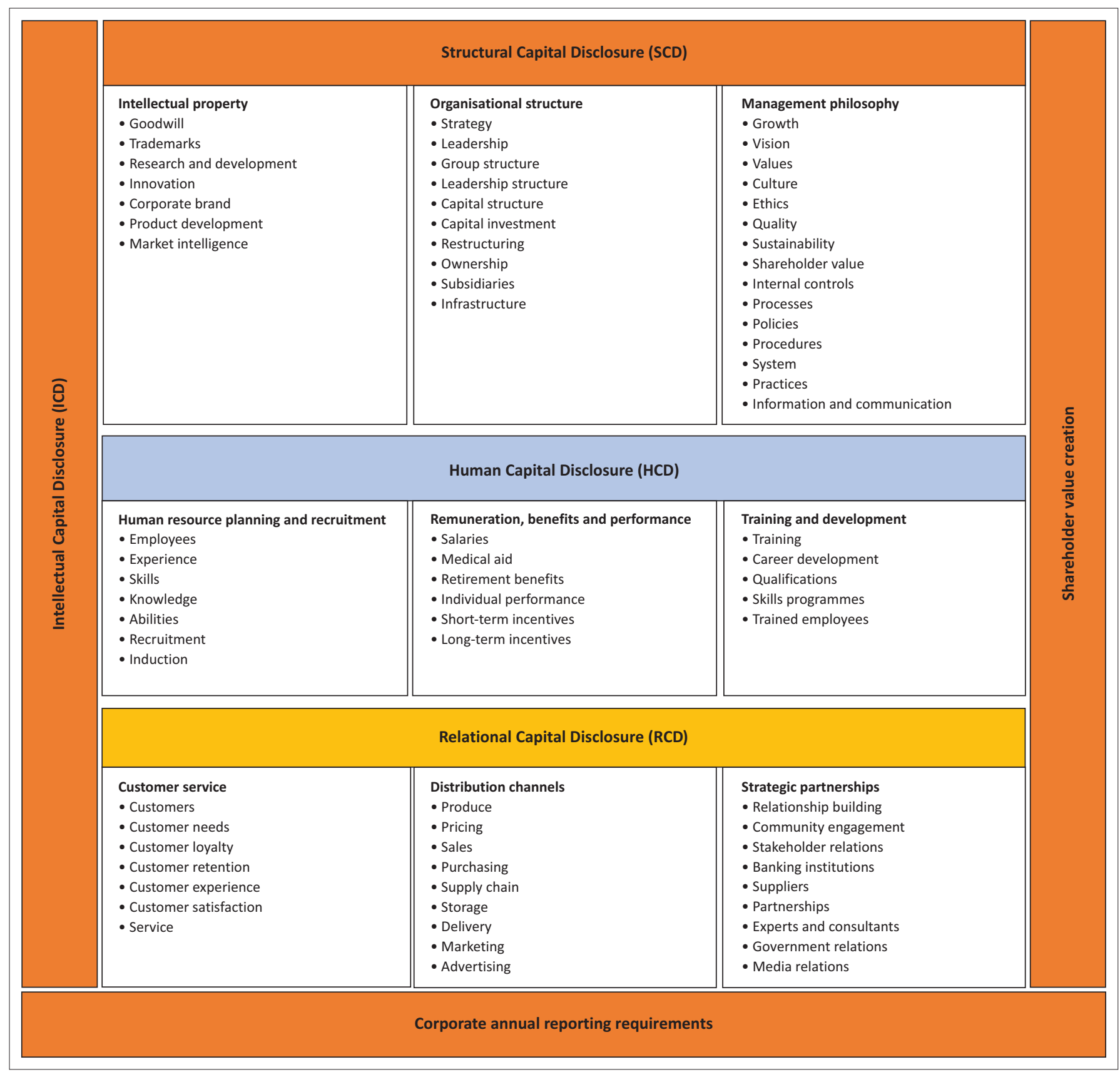

FIGURE 1: Intellectual capital disclosure measurement conceptual framework.

for corporate valuation by investors (Singh \& Kansal, 2011). SCD is often disclosed in aggregate terms, and not clearly isolated per sub-dimensions to understand how each intangible asset creates value.

HCD regarding plans to maximise the value of people's embodied assets is useful for predicting future business returns (Magau, Roodt, \& Van Zyl, 2021). Disclosed information on the implementation of key human resource (HR) practices such as workforce planning, recruitment, selection, development, performance and rewards can signal the companies' utilisation of $\mathrm{HC}$ for creating shareholder value (Adams et al., 2013; Motokawa, 2015; O'Donnell, Kramar, \& Dyball, 2012). Huang, Luther, Tayles and Haniffa (2013) confirmed that when information about HR planning and recruitment is disclosed in the annual reports, it conveys the company's potential to create value, whereas the disclosure of information about remuneration practices is required in terms of King IV on corporate governance, IFRS and as part of the Johannesburg Stock Exchange (JSE) listing requirements (Cassim \& Madlela, 2017; Kim \& Taylor, 2011). HCD of employee performance indicators, training and development also demonstrates the utilisation of people to achieve business objectives in the organisation (Sürdü, Çalıskan, \& Esen, 2020).

RCD is one of the determinants of organisational market value together with SCD and HCD (Adams et al., 2013; Abdolmohammadi, 2005; Abhayawansa \& Guthrie, 2016; Petty \& Guthrie, 2000). Measured in terms of customer service, distribution channels and stakeholder partnerships, information disclosed on RC reflects the organisation's 
relationship with both its internal and external environments (Abhayawansa \& Guthrie, 2016; Orens, Aerts, \& Lybaert, 2009; Tejedo-Romero, Rodrigues, \& Craig, 2017). Arvidsson (2011) supported the disclosure of customer service information as a key non-financial indicator that is useful in predicting future financial performance. Managing the flow of goods effectively requires the company to build relationships with multiple distributors, select appropriate distribution channels and manage costs (Neves, Zuurbier, \& Campomar, 2001), and such disclosure reflects customerorientation (Abhayawansa \& Guthrie, 2016). Tejedo-Romero et al. (2017) concluded that this information including the companies' transparency about their relationships with, for instance, suppliers and customers reinforce stakeholder engagement.

Therefore, this literature survey guided the construction of ICD measurement scale.

\section{Constructing the intellectual capital disclosure measurement scale}

A measurement scale determines the extent of ICD by scoring the presence of items in the annual report with either 1 for disclosed or 0 for not disclosed (Cardi, Mazzoli, \& Severini, 2019; Nielsen, Rimmel, \& Yosano, 2015). Another two-point scale means 1 for information disclosed qualitatively and 2 for information disclosed quantitatively (García-Meca et al., 2005; Whiting \& Miller, 2008). Oliveira et al. (2006) used a threepoint scale by scoring 0 for no information disclosed, 1 for information disclosed qualitatißvely, and 2 for information disclosed quantitatively. Another three-point scale was used by Guthrie et al. (2006) by scoring 1 for information that is discursive, 2 for information that is in numerical terms, and 3 for information that is in monetary terms. In a four-point scale, Vandemaele et al. (2005) scored 0 for no information disclosed, 1 for information disclosed qualitatively, 2 for information disclosed quantitatively, and 3 for information disclosed graphically. Similarly, Gerpott et al. (2008) scored 0 for no information disclosed, 1 for general information disclosure, 2 for substantial qualitative or quantified disclosure, and 3 for combination of qualitative and quantitative information.

A six-point scale was used by scoring 0 for non-disclosure; 1 for disclosure is immaterial to the financial well-being and results of the company, 2 for information disclosed obscurely whilst other topics and themes are discussed, 3 for information disclosed narratively by clearly showing its influence on the company or its policies, 4 for information disclosed in monetary terms or physical quantities, and 5 represents information disclosed in monetary or physical quantities and narrative statements (An \& Davey, 2010; Schneider \& Samkin, 2008). It appears that all these abovementioned scales are restricted in terms of measurement range. Therefore, there is a need to investigate a seven-point scale for capturing a broad range of ICD in annual reports. This scale is comprehensive for assessing the extent of information disclosed (An \& Davey, 2010) and determining the transparency of companies' annual reporting (Cheung,
Jiang, \& Tan, 2010). Scale development with selected items must yield acceptable mean values (Pather \& Uys, 2008) for inclusion in the final index. For assessing the internal consistency of disclosure indexes, Urquiza, Navarro and Trombetta (2009) indicated that internal consistency reliability coefficients above $\alpha=0.60$ should be obtained, and this requirement was taken into consideration.

The research design of the study will be discussed next, to explain how the data used in this study was generated.

\section{Research design Research approach}

A quantitative based cross-sectional study was undertaken by using the ICD measurement framework to guide the extraction of data from the annual reports of 150 companies listed in the JSE. In doing so, a disclosure index with a seven-point response scale was utilised across 75 items categorised into SCD, HCD and RCD. Cross-sectional design is suitable for IC studies examining the prevalence of disclosure in annual reports of the public listed companies in a given point in time (Alfraih, 2018; An \& Davey, 2010; Anifowose et al., 2017; Devalle et al., 2016). These studies do not yield a trend analysis as data are only captured across predefined variables in a specific point in time which would have been the case with longitudinalbased research.

\section{Research method}

\section{Research participants and sampling}

Johannesburg Stock Exchange-listed companies (a list was obtained from the JSE) form the research population targeted for this research project. A total of 150 Annual Reports of the JSE listed companies were selected for the period of 2015 to 2016 through a purposive sampling of top (75) and low (75) performing companies. This technique focuses on predefined criteria where participating companies are expected to comply with the anßnual reporting regulations (Bowrin, 2018). As part of the criteria for inclusion, the JSE listed companies were required to have published audited financial results in the year 2015 to 2016. From this list, suspended companies and those with incomplete information were removed before deriving a final sample. Subsequently, the annual reports were obtained from the companies' websites for data extraction using a predefined 7-point response scale.

\section{Measurement instrument}

A measurement instrument also referred to as a disclosure index containing 75 items with an ordinal response scale was constructed to extract data from the annual reports. Ordinal measures are used to assess qualitative and quantitative information in annual reports (Bukh, Nielsen, Gormsen, \& Mouritsen, 2005; Husin, Hooper, \& Olesen, 2012). Dammak, Triki and Boujelbene (2010) used a disclosure index with 71 items to assess the voluntary 
disclosure of ICD on a 0 to 1 response scale. Similarly, an ICD disclosure index with 78 items also with 0 to 1 response scale was found useful in examining ICD towards corporate performance (Cardi et al., 2019; Nielsen et al., 2015). In this study, the ICD dimensions (SCD, HCD and RCD) were utilised as follows in the construction of a 7-point disclosure index taking into consideration the reflective measures than formative measures (Park, Lee, \& Chae, 2017):

\section{Structural capital disclosure construct}

The SCD dimension with three sub-dimensions, namely, intellectual property (7 items), organisational culture (10 items) and management philosophy (15 items) allow investors to determine the companies' decisions regarding the maximisation of intangible assets (Arvidsson, 2011; Burmann et al., 2016; Dominguez, 2011; Lenciu \& Matiș, 2014; Sonnier, 2008).

To test for the internal consistency, the Cronbach alpha for measuring the SCD is acceptable if it is above 0.70 (Biscotti \& D’Amico, 2016; Milne \& Adler, 1999).

\section{Human capital disclosure construct}

Literature survey confirmed that HCD is gaining prominence (Adams et al., 2013; Huang et al., 2013; Motokawa, 2015; O'Donnell et al., 2012), especially since the adoption of integrated reporting that encourages the voluntary disclosure of information pertaining to $\mathrm{HC}$. The three HCD sub-dimensions included HR planning and recruitment (7 items), remuneration, benefits and performance ( 6 items) and training and development (5 items). The internal consistency of the HCD dimension is also acceptable above the Cronbach alpha of 0.70 (Biscotti \& D'Amico, 2016; Milne \& Adler, 1999).

\section{Relational capital disclosure construct}

Quite evident from the literature is that RCD about customer service ( 7 items), distribution channels ( 9 items) and stakeholder partnerships ( 9 items) is also essential for business valuation (Abdolmohammadi, 2005; Abhayawansa \& Guthrie, 2016; Adams et al., 2013; Petty \& Guthrie, 2000). The Cronbach alpha for measuring RCD was calculated at $\alpha=0.68$ in a study by Martini, Corvino, Doni and Rigolini (2016), which was acceptable. Biscotti and D'Amico (2016) and Milne and Adler (1999), on the other hand, determined that a Cronbach alpha above 0.70 is appropriate for measuring the aggregate constructs of the disclosure index for RC.

Subsequently, a 7-point response scale shown in Table 1 completed the construction of the disclosure index with SCD, HCD and RCD constructs of ICD.

\section{Data collection}

The published annual reports are available in the public domain; therefore, there were no ethical concerns related to confidentiality, except that the data had to be reported accurately (Thomas, 2012). In this study, a dictionary of keywords was developed as part of the disclosure index, in line with the IC dimensions, and used to (1) locate the relevant text electronically in the annual reports, (2) read and understand meaning in the context of IC and (3) accurately score the text (in Microsoft Excel). Abeysekera (2010) and Krippendorff (2013) emphasised the importance of accuracy in classifying text, ensuring that it corresponds with a predefined standard or norm representing IC items when searching for text and meaning in annual reports. Wagiciengo and Belal (2012) recommended that because this is labour-intensive and time-consuming, sufficient intervals be taken from time to time to ensure careful reading and honest data capturing. In this present study, this process took 13 months to complete. The un-weighted method determining the presence of items in the annual report was used instead of the weighted procedure which examines the quality of disclosure (Hooks, Coy, \& Davey, 2001).

\section{Pilot study}

Karanges, Johnston, Beatson and Lings (2015) emphasised the importance of pilot studies in quantitative research. To improve the integrity and quality of the data-capturing process, a pilot process was conducted in the present study using the Top 40 JSE-listed companies for the year 2015 to 2016 to identify and eliminate measures with low mean values. Firstly, the disclosure index with a 4-point scale initially contained 111 items (later reduced to 75 items), with 44 for SCD, 28 for HCD and 39 for RCD. Feedback extracted from the pilot process was used to improve the disclosure index. Initially, the disclosure index produced low reliability coefficients because of a restriction of range of a 4-point scale used in the pilot process, and hence it was later expanded to a 7-point scoring system. Therefore, this final scale was used on a total sample of 150 companies that included the initial pilot using 40 items. Subsequently, reliability statistics improved in all the ICD dimensions as presented in the statistical analysis.

\section{Statistical analysis}

Firstly, the disclosure index must be examined to test the reliability of the instrument (Bozzolan, Favotto, \& Ricceri, 2003). Accordingly, a newly constructed instrument was subjected to an exploratory factor analysis (EFA) instead of confirmatory factor analysis (CFA), which was also the case in another research examining the voluntary disclosure of

TABLE 1: The 7-point intellectual capital disclosure response scale.

\begin{tabular}{|c|c|c|c|c|c|c|}
\hline $\begin{array}{l}\text { Information not } \\
\text { disclosed }\end{array}$ & $\begin{array}{l}\text { Information disclosed in } \\
\text { qualitative terms, with } \\
\text { less emphasis }\end{array}$ & $\begin{array}{l}\text { Information disclosed in } \\
\text { qualitative terms, with } \\
\text { more emphasis }\end{array}$ & $\begin{array}{l}\text { Information disclosed in } \\
\text { quantitative terms }\end{array}$ & $\begin{array}{l}\text { Information disclosed in } \\
\text { combined quantitative } \\
\text { and qualitative terms }\end{array}$ & $\begin{array}{l}\text { Information disclosed in } \\
\text { monetary values only }\end{array}$ & $\begin{array}{l}\text { Information disclosed in } \\
\text { combined monetary and } \\
\text { qualitative terms }\end{array}$ \\
\hline 0 & 1 & 2 & 3 & 4 & 5 & 6 \\
\hline
\end{tabular}


ICD (Dammak et al., 2010). EFA is useful when testing a new instrument that has not been subjected to reliability and validity tests, whereas CFA is considered to verify or confirm an existing instrument (Hurley et al., 1997). A factor analysis identifies patterns of relationships between items and constructs by reducing observable variables to fewer latent variables with common variance (Bartholomew, Knott, \& Moustaki, 2011). Procedurally, the first-level factor analysis statistically examined the covariance relationship amongst observed items to derive latent factors (unobserved) through the principal component factor extraction method, using varimax (orthogonal) rotation (Mulaik, 2009).

The artificial factors were subsequently removed with a second level factor analysis. To this effect, the Kaiser-MeyerOlkin (KMO) measure of sampling adequacy (MSA) and Bartlett's test of sphericity were calculated. Kaiser (1974) suggested that a KMO measure of 0.90 is marvellous, 0.80 is meritorious, 0.70 is middling, 0.60 is mediocre, 0.50 is miserable and below 0.5 is unacceptable. Bartlett's test of sphericity is considered to be statistically significant at $\rho \leq$ 0.05 . The retention of the number of latent factors followed the Kaiser rule, which requires an eigenvalue larger than unity (> 1.00) (Larsen \& Warne, 2010). A MSA $\geq 0.70$ and a significant value for Bartlett's test of sphericity confirm that a solution is suitable for multivariate analysis (Bartlett, 1950; Kaiser, 1974). The second level factor analysis follows the same procedure to further reduce the emerged observable variables to fewer latent constructs (Schepers, 1992). Subsequently, the mean scores of all items making up each factor were calculated. Tabachnick and Fidell (2001) suggested a 0.32 threshold for at least one inter-factor correlation in non-orthogonal rotation. During the extraction process, cross-loadings became evident, where variables load on at least two or more factors simultaneously. Items with cross-loading values higher than 0.30 were removed.

\section{Ethical considerations}

It is always advisable to follow stringent ethical considerations when conducting research and disseminating research findings (Suri, 2008). It is also imperative to adhere to the research ethics policy and guidelines of the relevant research institution. In the present study, a multidisciplinary literature review was undertaken by using the following key search words: HC, IC, intangibles, intangible assets, HR, customer capital, RC, SC and HC theory. This enabled the researcher to cover a much wider literature base, including a variety of opposing views on the topic of IC. Bornmann and Daniel (2008) provided useful insights on the citations behaviour which scholars must avoid. These were duly considered in this study.

\section{Results}

\section{Results of the factor analysis}

The results are presented according to the first- and secondlevel factor analysis. The iterative item reliabilities are also presented per factor. Firstly, the results of the factor analysis for SCD are discussed.

\section{Structural capital disclosure}

The SCD dimension contained 7 items in intellectual property, 10 items in organisational structure and 15 items in management philosophy, which amounted to a total of 32 items.

\section{First-level factor analysis}

Initially, an exploration of item correlations was carried out through a $32 \times 32$ inter-correlation matrix (too large to insert here, but available upon request), which provided a detailed assessment of the sampling adequacy. The resultant item correlations were sufficient to perform the KMO MSA test which yielded an index of 0.770 and Bartlett's test of sphericity significant at $p=0.001\left(\chi^{2}=1213.103 ; \mathrm{df}=496\right)$. This complied with the required sampling adequacy for executing an EFA (Kaiser, 1974) and implied a sufficient correlation between items (Bartlett, 1950).

To determine the appropriateness of the factor model, the eigenvalues of the unreduced item correlation matrix were calculated based on the criterion of roots greater than unity (Kaiser, 1961). Table 2 presents the eigenvalues of the 11 extracted factors.

Table 2 shows that 11 factors were postulated, based on the eigenvalues greater than unity, explaining $63 \%$ of the variance in the factor space. Subsequently, principal axis factoring and varimax rotation with Kaiser normalisation were used to extract the unobserved factors. The factor matrix rotated with Kaiser normalisation converged in 45 iterations, and the 11 items with values greater than 0.3 were retained.

\section{Second-level factor analysis}

The aim of a second-level factor analysis is to avoid the creation of artificial factors, also referred to as artifactors. This technique further assessed the underlying patters of relationships by rearranging the data into a smaller set of matrices accounting for the interrelations. During this procedure, a reduced $11 \times 11$ inter-correlation matrix was subjected to an exploration of item correlations.

The degree of linear relationships was sufficient to proceed with determining the sampling adequacy. The KMO MSA criteria and Bartlett's test of sphericity were computed for the inter-correlated matrices, and the resultant item correlations were sufficient to perform the KMO MSA test which produced an index 0.806 and Bartlett's test of sphericity significant at $p=0.001\left(\chi^{2}=320.628 ; \mathrm{df}=55\right)$. These statistics were all above the recommended threshold (Kleinheksel \& Ritzhaupt, 2017) and confirmed the inter-correlation to be factorable. On calculating the eigenvalues of the unreduced item correlation matrix, a one-factor solution was postulated. Table 3 provides the results of the postulated factors based on the eigenvalues larger than unity. 
TABLE 2: Initial eigenvalues for structural capital disclosure (first-level factor analysis).

\begin{tabular}{|c|c|c|c|}
\hline \multirow[t]{2}{*}{ Factor SCD } & \multicolumn{3}{|c|}{ Initial eigenvalues } \\
\hline & Total & $\%$ of Variance & Cumulative \% \\
\hline 1 & 6.143 & 19.196 & 19.196 \\
\hline 2 & 2.110 & 6.593 & 25.788 \\
\hline 3 & 1.930 & 6.032 & 31.821 \\
\hline 4 & 1.656 & 5.174 & 36.995 \\
\hline 5 & 1.430 & 4.467 & 41.462 \\
\hline 6 & 1.359 & 4.246 & 45.708 \\
\hline 7 & 1.259 & 3.936 & 49.644 \\
\hline 8 & 1.175 & 3.672 & 53.316 \\
\hline 9 & 1.109 & 3.467 & 56.783 \\
\hline 10 & 1.074 & 3.356 & 60.138 \\
\hline 11 & 1.020 & 3.186 & 63.324 \\
\hline 12 & 0.944 & 2.950 & 66.275 \\
\hline 13 & 0.915 & 2.859 & 69.134 \\
\hline 14 & 0.842 & 2.632 & 71.766 \\
\hline 15 & 0.766 & 2.395 & 74.161 \\
\hline 16 & 0.756 & 2.362 & 76.522 \\
\hline 17 & 0.708 & 2.213 & 78.735 \\
\hline 18 & 0.689 & 2.154 & 80.889 \\
\hline 19 & 0.652 & 2.036 & 82.925 \\
\hline 20 & 0.620 & 1.939 & 84.864 \\
\hline 21 & 0.603 & 1.884 & 86.747 \\
\hline 22 & 0.556 & 1.737 & 88.484 \\
\hline 23 & 0.513 & 1.603 & 90.087 \\
\hline 24 & 0.457 & 1.427 & 91.514 \\
\hline 25 & 0.423 & 1.323 & 92.837 \\
\hline 26 & 0.406 & 1.268 & 94.105 \\
\hline 27 & 0.388 & 1.212 & 95.317 \\
\hline 28 & 0.356 & 1.112 & 96.428 \\
\hline 29 & 0.309 & 0.966 & 97.394 \\
\hline 30 & 0.301 & 0.940 & 98.334 \\
\hline 31 & 0.276 & 0.863 & 99.197 \\
\hline 32 & 0.257 & 0.803 & 100.000 \\
\hline
\end{tabular}

Extraction method: principal axis factoring; SCD, structural capital disclosure.

TABLE 3: Initial eigenvalues for structural capital disclosure (second-level factor analysis).

\begin{tabular}{lccc}
\hline Factor SCD & \multicolumn{3}{c}{ Initial eigenvalues } \\
\cline { 2 - 4 } & Total & \% of variance & Cumulative \% \\
\hline 1 & 2.413 & 60.328 & 60.328 \\
2 & 0.599 & 14.977 & 75.305 \\
3 & 0.544 & 13.610 & 88.915 \\
4 & 0.443 & 11.085 & 100.000 \\
\hline
\end{tabular}

Extraction method: principal axis factoring; SCD, structural capital disclosure.

The one factor postulated in Table 3 and extracted by means of principal axis factoring and varimax rotation with Kaiser normalisation converged after eight iterations. This factor explained $60 \%$ of the variance in the factor space. The factor loadings and communalities presented in Table 4 represent the derived factor structure. Tabachnick and Fidell (2001) suggested 0.32 as a rule of thumb in factor loadings.

Upon completion, all items inter-correlating with communalities above 0.20 indicated that the variance was explained by all the common items (Child, 2006) and confirmed the factor structure.
TABLE 4: Factor loadings and extracted communalities for structural capital disclosure.

\begin{tabular}{lcc}
\hline Factor SCD items & $\begin{array}{c}\text { Factor } \\
\text { loadings }\end{array}$ & $\begin{array}{c}\text { Extracted } \\
\text { communalities }\end{array}$ \\
\hline Group structure (IP5, MP8 and MP12) & 0.781 & 0.610 \\
Goodwill (OS2, OS6, OS10, MP6, MP10 and MP13) & 0.673 & 0.453 \\
Leadership (IP4, IP7, MP1 and MP14) & 0.665 & 0.443 \\
Innovation (MP2, MP3 and MP4) & 0.626 & 0.392 \\
\hline SCD, structural capital disclosure; IP, intellectual property; OS, organisational structure; MP, \\
management philosophy.
\end{tabular}

\section{Iterative item reliabilities}

Having extracted the appropriate factor, the iterative item reliability procedure was used to examine the reliability of the items with correlations $>0.30$. Ultimately, this factor retained 16 items within the three theoretical sub-dimensions, as reported in Table 5.

It is evident from Table 5 that individual items yielded Cronbach alpha coefficients ranging from 0.816 to 0.823 . Overall, the SCD dimension was found to be reliable, with a Cronbach alpha of 0.829 , which is adequate. Urquiza et al. (2009) indicated that reliability values above $\alpha=0.60$ confirm the internal consistency of a disclosure index. The results concluded the factor analysis for the SCD dimension.

The next section presents the results of the factor analysis of HCD.

\section{Human capital disclosure}

The 18 items of the HCD dimension were initially grouped as follows: seven items in HR planning and recruitment, six items in remuneration and benefits and five items in training and development. These variables measured the extent to which HR practices leveraged the contribution of HCD towards business performance. This preliminary composition was subjected to factor analyses.

\section{First-level factor analysis}

In order to determine whether the item inter-correlations were substantial $(>0.30), 18 \times 18$ inter-item correlations were calculated (too larger to insert here), yielding an anti-image correlation matrix with acceptable values to test for overall significance and sampling adequacy. The KMO MSA produced 0.813 and Bartlett's test of sphericity $p=0.001\left(\chi^{2}=\right.$ 801.530; df $=153$ ) confirming the inter-correlation to be factorable.

The next step was to extract an interpretable factor from the original items. This was performed by calculating the eigenvalues of the unreduced item-correlation matrix on the criterion of roots greater than unity (Kaiser, 1974). Table 6 presents the eigenvalues.

Table 6 suggests that a six-factor solution accounting for $62 \%$ of the variance in the factor space with eigenvalues larger than unity was proposed. Principal axis factoring and varimax rotation with Kaiser normalisation were used to extract six factors that converged after 19 iterations. Retained 
TABLE 5: Iterative item reliability analysis: Structural capital disclosure.

\begin{tabular}{|c|c|c|c|c|c|c|}
\hline Item per dimension & Sub-dimensions & $\begin{array}{l}\text { Scale mean if } \\
\text { item deleted }\end{array}$ & $\begin{array}{l}\text { Scale variance if } \\
\text { item deleted }\end{array}$ & $\begin{array}{l}\text { Corrected item-total } \\
\text { correlation }\end{array}$ & $\begin{array}{l}\text { Squared multiple } \\
\text { correlation }\end{array}$ & $\begin{array}{c}\text { Cronbach's alpha if } \\
\text { item deleted }\end{array}$ \\
\hline IP4 & Intellectual property & 32.31 & 156.941 & 0.512 & 0.467 & 0.816 \\
\hline IP5 & & 31.73 & 155.905 & 0.432 & 0.284 & 0.820 \\
\hline IP7 & & 32.49 & 158.466 & 0.420 & 0.383 & 0.821 \\
\hline os2 & Organisational structure & 31.81 & 158.130 & 0.538 & 0.395 & 0.815 \\
\hline OS6 & & 29.84 & 142.914 & 0.500 & 0.318 & 0.818 \\
\hline OS10 & & 31.23 & 144.673 & 0.508 & 0.388 & 0.816 \\
\hline MP1 & Management philosophy & 28.89 & 154.611 & 0.471 & 0.293 & 0.818 \\
\hline MP2 & & 32.39 & 168.978 & 0.306 & 0.280 & 0.827 \\
\hline MP3 & & 32.16 & 166.363 & 0.486 & 0.390 & 0.821 \\
\hline MP4 & & 32.41 & 165.397 & 0.528 & 0.375 & 0.820 \\
\hline MP6 & & 31.62 & 158.841 & 0.409 & 0.225 & 0.821 \\
\hline MP8 & & 32.07 & 155.370 & 0.432 & 0.238 & 0.820 \\
\hline MP10 & & 31.08 & 146.839 & 0.579 & 0.438 & 0.810 \\
\hline MP13 & & 31.98 & 161.013 & 0.407 & 0.282 & 0.821 \\
\hline MP14 & & 31.71 & 160.850 & 0.372 & 0.220 & 0.823 \\
\hline
\end{tabular}

No. of cases $=150 ;$ No. of items $=16 ;$ Cronbach's alpha coefficient $=0.849$.

SCD, structural capital disclosure; IP, intellectual property; OS, organisational structure; MP, management philosophy

TABLE 6: Initial eigenvalues human capital disclosure (first-level factor analysis).

\begin{tabular}{lccc}
\hline Factor HCD & \multicolumn{3}{c}{ Initial eigenvalues } \\
\cline { 2 - 4 } & Total & \% of variance & Cumulative \% \\
\hline 1 & 4.896 & 27.199 & 27.199 \\
2 & 1.557 & 8.650 & 35.849 \\
\hline & 1.445 & 8.029 & 43.878 \\
5 & 1.179 & 6.548 & 50.426 \\
6 & 1.122 & 6.233 & 56.659 \\
7 & 1.049 & 5.825 & 62.484 \\
8 & 0.984 & 5.465 & 67.949 \\
9 & 0.883 & 4.905 & 72.854 \\
10 & 0.736 & 4.089 & 76.943 \\
11 & 0.728 & 4.046 & 80.990 \\
12 & 0.670 & 3.721 & 84.711 \\
13 & 0.600 & 3.331 & 88.042 \\
14 & 0.578 & 3.208 & 91.251 \\
15 & 0.459 & 2.553 & 93.803 \\
16 & 0.415 & 2.303 & 96.106 \\
17 & 0.305 & 1.695 & 97.802 \\
18 & 0.243 & 1.349 & 99.150 \\
\hline & 0.153 & 0.850 & 100.000 \\
\hline
\end{tabular}

Extraction method: Principal axis factoring. HCD, human capital disclosure.

factors carrying the greatest amount of variance were found logically appropriate for second-level factor analysis.

\section{Second-level factor analysis}

When conducting second-level factor analysis, a reduced $6 \times$ 6 inter-item correlation matrix was computed by diffusing the pattern of item relationships in order to determine the extent of correlation between items. This process led to the allocation of items into appropriate factors. The item intercorrelation matrix explains the underlying meaning of the corresponding factors and showed that the items were moderately correlated with each other. The resultant item correlations were sufficient to perform the KMO MSA test which yielded an index of 0.736 and Bartlett's test of sphericity significant at $p=0.001\left(\chi^{2}=125.357 ; \mathrm{df}=15\right)$. The results confirmed that the correlation matrix was an identity matrix and satisfactory for factor analysis (Bartlett, 1950;
Kaiser, 1974; Kleinheksel \& Ritzhaupt, 2017). The next step was to calculate the eigenvalues of the unreduced item correlation matrix on the criterion of roots greater than unity (Kaiser, 1974). Principal axis factoring with varimax rotation and Kaiser normalisation was executed to extract a one-actor solution that converged after 10 iterations. Table 7 provides the extracted eigenvalues.

The one factor postulated explained $38 \%$ of the variance in the factor space. Principal axis factoring with varimax rotation and Kaiser normalisation was executed in extracting a one factor solution that converged after 10 iterations. The results indicated a shift in the ultimate factor composition, as determined through the factor loadings and communalities, presented in Table 8.

Items with communalities less than 0.20 may not be related to other items (Child, 2006). However, factor loadings above 0.32 are sufficient (Tabachnick \& Fidell, 2001) to retain the HC factor structure with three components (employees, knowledge and recruitment). This result confirmed the HCD factor structure with all related items.

\section{Iterative item reliabilities}

The HCD dimension originally consisted of 18 items. All 18 items were retained after the second-level factor analysis. Table 9 provides the reliability statistics.

All items achieved Cronbach alpha coefficients ranging from 0.777 to 0.817 , and the $\mathrm{HC}$ dimension found to be reliable at 0.806. A Cronbach alpha coefficient of 0.70 or greater indicates that the disclosure index consistently measures the underlying constructs (Urquiza et al., 2009). The results concluded the factor analysis for the HCD dimension.

\section{Relational capital disclosure}

Relational capital disclosure contained 25 items: seven items in customer service, nine items in distribution channels and nine items in strategic partnerships. This list of items 
represents the key variables in measuring the impact of disclosure of HC in improving stakeholder relationships. The RCD dimension was subjected to the following factor analyses.

\section{First-level factor analysis}

A $25 \times 25$ inter-item correlation matrix (too large to insert here) was computed in order to determine the extent of correlations, yielding an anti-image correlation matrix confirming the correlations and the factor's appropriateness to test for sampling adequacy and significance. This led to the computation of the KMO MSA yielding an index of 0.702 and Bartlett's test of sphericity significant at $p=0.001$ $\left(\chi^{2}=717.313 ; \mathrm{df}=300\right)$ confirming the factorability of the inter-correlation matrix.

TABLE 7: Initial eigenvalues for human capital disclosure (second-level factor analysis).

\begin{tabular}{lccc}
\hline Factor & \multicolumn{3}{c}{ Initial eigenvalues } \\
\cline { 2 - 4 } & Total & \% of variance & Cumulative \% \\
\hline 1 & 2.304 & 38.394 & 38.394 \\
2 & 0.963 & 16.049 & 54.443 \\
3 & 0.867 & 14.448 & 68.891 \\
4 & 0.820 & 13.675 & 82.566 \\
5 & 0.592 & 9.862 & 92.428 \\
6 & 0.454 & 7.572 & 100.000 \\
\hline
\end{tabular}

Extraction method: Principal axis factoring.

TABLE 8: Factor loadings and extracted communalities for human capital disclosure.

\begin{tabular}{lcc}
\hline Factor HCD items & Factor loadings & $\begin{array}{c}\text { Extracted } \\
\text { communalities }\end{array}$ \\
\hline Employees (TD4, TD5, TD1, HR6, HR1 and RB4) & 0.772 & 0.597 \\
Knowledge (HR and HR3) & 0.615 & 0.378 \\
Recruitment (HR5, RB6 and RB5) & 0.590 & 0.348 \\
Experience (RB2 and RB3) & 0.426 & 0.181 \\
Abilities (TD3 and HR7) & 0.345 & 0.119 \\
Skills (HR2, TD2 and RB1) & 0.246 & 0.061 \\
\hline
\end{tabular}

$H C D$, human capital disclosure; HR, human resources; TD, training \& development; RB, renumeration $\&$ benefits.
A KMO MSA value of 0.60 or greater confirmed factorability (Kaiser, 1974; Tabachnick \& Fidell, 2007). The next step was to extract an interpretable factor by calculating the eigenvalues of the unreduced item-correlation matrix on the criterion of roots greater than unity (Kaiser, 1974). This resulted in the extraction of eight factors, as shown in Table 10.

Eight factors with eigenvalues larger than unity were postulated and converged after 10 iterations, explaining a total of $56 \%$ variance in the factor space. Principal axis factoring with varimax rotation and Kaiser normalisation were performed. These postulated eight factors were subjected to a second-level factor analysis.

\section{Second-level factor analysis}

The $8 \times 8$ inter-item correlation matrix was computed in order to further explore the item correlations and to force a one-factor solution from this itemised structure. This was sufficient for the KMO MSA test of sampling adequacy which produced an index of 0.775 and Bartlett's test of sphericity significant at $p=0.001\left(\chi^{2}=157.580 ; \mathrm{df}=28\right)$ confirming the factorability of the inter-correlation matrix. Subsequently, the eigenvalues of the unreduced item correlation matrix were calculated. Table 11 provides the extracted eigenvalues.

The eigenvalues larger than unity suggested a two-factor solution explaining a total of $46 \%$ variance in the factor space. Principal axis factoring and varimax rotation with Kaiser normalisation converged after 25 iterations. The factor loadings and communalities presented in Table 12, represent the derived factor structure.

Only two items, namely customer needs and customer retention loaded on Factor 2, with loadings of 0.722 and 0.342, respectively. These items also cross-loaded on Factor 1 at 0.382 and 0.124 . The rule of thumb is to retain a factor loading

TABLE 9: Iterative item reliability analysis: Human capital disclosure.

\begin{tabular}{|c|c|c|c|c|c|c|}
\hline Item per dimension & Sub-dimensions & $\begin{array}{c}\text { Scale mean if item } \\
\text { deleted }\end{array}$ & $\begin{array}{c}\text { Scale variance if item } \\
\text { deleted }\end{array}$ & $\begin{array}{l}\text { Corrected item-total } \\
\text { correlation }\end{array}$ & $\begin{array}{l}\text { Squared multiple } \\
\text { correlation }\end{array}$ & $\begin{array}{c}\text { Cronbach's alpha if item } \\
\text { deleted }\end{array}$ \\
\hline HR1 & \multirow{7}{*}{$\begin{array}{l}\text { HR planning and } \\
\text { recruitment }\end{array}$} & 43.47 & 157.056 & 0.528 & 0.360 & 0.800 \\
\hline HR2 & & 43.20 & 164.523 & 0.134 & 0.108 & 0.813 \\
\hline HR3 & & 44.96 & 153.542 & 0.574 & 0.456 & 0.796 \\
\hline HR4 & & 45.65 & 164.002 & 0.250 & 0.239 & 0.809 \\
\hline HR5 & & 46.24 & 164.801 & 0.233 & 0.208 & 0.810 \\
\hline HR6 & & 45.01 & 148.866 & 0.478 & 0.349 & 0.797 \\
\hline HR7 & & 45.72 & 159.961 & 0.367 & 0.256 & 0.805 \\
\hline TD1 & \multirow[t]{5}{*}{ Training and development } & 43.34 & 131.004 & 0.703 & 0.658 & 0.777 \\
\hline TD2 & & 44.66 & 157.259 & 0.207 & 0.109 & 0.814 \\
\hline TD3 & & 43.42 & 166.366 & 0.035 & 0.095 & 0.817 \\
\hline TD4 & & 44.61 & 135.823 & 0.654 & 0.751 & 0.782 \\
\hline TD5 & & 44.65 & 134.953 & 0.673 & 0.754 & 0.780 \\
\hline RB1 & \multirow[t]{6}{*}{ Remuneration and benefits } & 42.03 & 164.032 & 0.101 & 0.108 & 0.816 \\
\hline RB2 & & 43.49 & 146.346 & 0.333 & 0.458 & 0.810 \\
\hline RB3 & & 42.65 & 142.215 & 0.494 & 0.493 & 0.795 \\
\hline RB4 & & 45.40 & 150.966 & 0.437 & 0.320 & 0.799 \\
\hline RB5 & & 42.65 & 148.644 & 0.425 & 0.267 & 0.800 \\
\hline RB6 & & 42.85 & 143.656 & 0.455 & 0.353 & 0.798 \\
\hline
\end{tabular}

No. of cases $=150 ;$ No. of items $=18 ;$ Cronbach's alpha coefficient $=0.806$.

$H R$, human resources, $T D$, training \& development, $R B$, renumeration \& benefits. 
TABLE 10: Initial eigenvalues for relational capital disclosure (first-level factor analysis).

\begin{tabular}{|c|c|c|c|}
\hline \multirow[t]{2}{*}{ Factor } & \multicolumn{3}{|c|}{ Initial eigenvalues } \\
\hline & Total & $\%$ of variance & Cumulative \% \\
\hline 1 & 4.363 & 17.453 & 17.453 \\
\hline 2 & 2.055 & 8.218 & 25.671 \\
\hline 3 & 1.659 & 6.638 & 32.309 \\
\hline 4 & 1.427 & 5.710 & 38.019 \\
\hline 5 & 1.296 & 5.185 & 43.204 \\
\hline 6 & 1.200 & 4.801 & 48.005 \\
\hline 7 & 1.126 & 4.504 & 52.509 \\
\hline 8 & 1.068 & 4.273 & 56.782 \\
\hline 9 & 0.996 & 3.985 & 60.768 \\
\hline 10 & 0.956 & 3.823 & 64.591 \\
\hline 11 & 0.924 & 3.697 & 68.288 \\
\hline 12 & 0.874 & 3.495 & 71.783 \\
\hline 13 & 0.792 & 3.168 & 74.951 \\
\hline 14 & 0.761 & 3.043 & 77.995 \\
\hline 15 & 0.718 & 2.873 & 80.867 \\
\hline 16 & 0.668 & 2.672 & 83.539 \\
\hline 17 & 0.626 & 2.503 & 86.042 \\
\hline 18 & 0.587 & 2.347 & 88.389 \\
\hline 19 & 0.521 & 2.086 & 90.475 \\
\hline 20 & 0.514 & 2.057 & 92.532 \\
\hline 21 & 0.446 & 1.782 & 94.314 \\
\hline 22 & 0.439 & 1.754 & 96.069 \\
\hline 23 & 0.357 & 1.428 & 97.497 \\
\hline 24 & 0.333 & 1.333 & 98.830 \\
\hline 25 & 0.293 & 1.170 & 100.000 \\
\hline
\end{tabular}

Extraction method: Principal axis factoring.

TABLE 11: Initial eigenvalues: relational capital disclosure (second-level factor analysis).

\begin{tabular}{lccc}
\hline Factor & \multicolumn{3}{c}{ Initial eigenvalues } \\
\cline { 2 - 4 } & Total & \% of variance & Cumulative \% \\
\hline 1 & 2.612 & 32.652 & 32.652 \\
2 & 1.140 & 14.255 & 46.907 \\
3 & 0.914 & 11.431 & 58.338 \\
4 & 0.801 & 10.014 & 68.352 \\
5 & 0.732 & 9.153 & 77.505 \\
6 & 0.685 & 8.566 & 86.071 \\
7 & 0.593 & 7.409 & 93.480 \\
8 & 0.522 & 6.520 & 100.000 \\
\hline
\end{tabular}

Extraction method: Principal axis factoring

of above 0.32 (Tabachnick \& Fidell, 2001). The customer needs item in both Factor 1 and Factor 2 measured the same construct, which resulted in Factor 1 being retained, because of more items with higher loadings. Item cross-loadings can be assigned to the factor with the highest loadings (Anagnostopoulos, Yfantopoulos, Moustaki, \& Niakas, 2013). Therefore, Factor 2 remained with one item only, customer retention, which loaded the highest, compared to Factor 1. Factor 2 was rendered invalid and omitted in further analyses, because of the one remaining item not being factorable.

Additionally, there were cross-loadings of two items, namely produce and customers in Factor 1 and Factor 2. This again
TABLE 12: Factor loadings and extracted communalities for relational capital disclosure.

\begin{tabular}{lccc}
\hline RC factor items & $\begin{array}{c}\text { Factor 1 } \\
\text { loadings }\end{array}$ & $\begin{array}{c}\text { Factor 2 } \\
\text { loadings }\end{array}$ & $\begin{array}{c}\text { Extracted } \\
\text { communalities }\end{array}$ \\
\hline Produce (SP9, DC4, DC9 and DC8) & 0.592 & 0.334 & 0.357 \\
Services (CS6 and CS5) & 0.566 & 0.145 & 0.333 \\
Customers (CS2, SP6, SP2 and RC2) & 0.536 & 0.530 & 0.395 \\
Customer experience (CS1 and CS3) & 0.493 & 0.288 & 0.250 \\
Customer satisfaction (SP1, CS4 and DC6) & 0.476 & 0.181 & 0.227 \\
Customer loyalty (SP4, SP8 and CS7) & 0.434 & 0.218 & 0.189 \\
Customer needs (SP3, DC7, SP5, DC5 and & 0.382 & 0.722 & 0.597 \\
DC1) & & & \\
Customer retention (DC3 and SP7) & 0.124 & 0.342 & 0.118 \\
\hline
\end{tabular}

$\mathrm{RC}$, relational capital; SP, strategic partnerships; CS, customer service; DC, distribution channels.

implied that both factors measured the same construct. Factor 1 was retained, as it had the highest loadings of 0.592 and 0.536 , respectively. In this way, a one-factor solution was forced.

\section{Iterative item reliabilities}

The 14 retained items in RCD produced the reliability statistics provided in Table 13.

Relational capital disclosure yielded a Cronbach alpha coefficient of 0.749 , with all 18 items ranging between 0.709 and 0.737 , which confirmed the internal consistency of this dimension. The results concluded the factor analysis for the $R C D$ dimension.

\section{Discussion}

Studies focused on the development of an ICD through factor analysis could not be obtained. The present study set out to use the ICD framework (SCD, HCD and RCD) for developing a disclosure index by selecting 75 items, with a 7-point response scale or scoring system for assessing the extent of ICD in the annual reports/integrated reports.

In this research, EFA was carried out with the internal consistency of the overall ICD generating a Cronbach's alpha coefficient (0.794), which is consistent with the recommendation by Urquiza et al. (2009) that reliability values above $\alpha=0.60$ for disclosure indexes are acceptable. ICD calculated by dividing the number of items disclosed in each dimension by the total number of all items across (Bukh et al., 2005) provided fairly distributed scores across the scale (0 to 6) indicating the extent of disclosure. Scores were unweighted by only examining the extent of ICD and not weighted as the priority of the scale was not to assess the quality of information disclosed (Hooks et al., 2001).

The next passage elaborates on the key findings based on the following three ICD measurement constructs.

\section{Structural capital disclosure measurement}

The SCD results generated high reliabilities of 0.829 Cronbach's alpha coefficient and item reliabilities ranging between 0.816 and 0.823 confirming that the items measured the same 
TABLE 13: Iterative item reliability analysis: Relational capital disclosure.

\begin{tabular}{|c|c|c|c|c|c|c|}
\hline Item per dimension & Sub-dimensions & $\begin{array}{c}\text { Scale mean if item } \\
\text { deleted }\end{array}$ & $\begin{array}{c}\text { Scale variance if item } \\
\text { deleted }\end{array}$ & $\begin{array}{c}\text { Corrected item-total } \\
\text { correlation }\end{array}$ & $\begin{array}{c}\text { Squared multiple } \\
\text { correlation }\end{array}$ & $\begin{array}{c}\text { Cronbach's alpha if item } \\
\text { deleted }\end{array}$ \\
\hline CS1 & Customer service & 36.02 & 151.349 & 0.341 & 0.255 & 0.720 \\
\hline CS2 & & 39.23 & 161.613 & 0.420 & 0.299 & 0.722 \\
\hline CS3 & & 39.45 & 161.658 & 0.308 & 0.219 & 0.725 \\
\hline CS4 & & 39.81 & 167.495 & 0.198 & 0.159 & 0.732 \\
\hline CS5 & & 39.50 & 160.279 & 0.317 & 0.293 & 0.724 \\
\hline CS6 & & 39.25 & 156.902 & 0.413 & 0.317 & 0.717 \\
\hline CS7 & & 35.95 & 154.058 & 0.353 & 0.282 & 0.719 \\
\hline $\mathrm{DC2}$ & Distribution channels & 37.21 & 151.605 & 0.270 & 0.270 & 0.729 \\
\hline DC4 & & 36.69 & 148.415 & 0.293 & 0.182 & 0.728 \\
\hline DC6 & & 38.31 & 147.221 & 0.376 & 0.282 & 0.716 \\
\hline DC8 & & 38.13 & 147.391 & 0.426 & 0.237 & 0.711 \\
\hline DC9 & & 39.23 & 161.267 & 0.225 & 0.131 & 0.730 \\
\hline SP1 & Strategic partnerships & 37.72 & 160.525 & 0.193 & 0.121 & 0.733 \\
\hline SP4 & & 35.13 & 164.393 & 0.128 & 0.136 & 0.737 \\
\hline SP6 & & 37.21 & 146.290 & 0.410 & 0.292 & 0.713 \\
\hline SP8 & & 36.95 & 149.299 & 0.344 & 0.250 & 0.720 \\
\hline SP9 & & 39.03 & 160.429 & 0.336 & 0.197 & 0.723 \\
\hline
\end{tabular}

No. of cases $=150 ;$ No. of items $=18 ;$ Cronbach's alpha coefficient $=0.749$.

underlying 'construct'. The Cronbach's alpha values of above 0.70 for disclosure indexes are considered acceptable (Biscotti \& D'Amico, 2016; Milne \& Adler, 1999). No cases of factor loadings were detected confirming the reliability of the construct. Consequently, the key SCD finding is that the scale used in the study empirically measured the presence of information in the annual reports in relation to the company's IP, OC and MP which are essential for enhancing corporate value (Bini et al., 2016; Burmann et al., 2016; Gamerschlag, 2013; García-Meca et al., 2005; Olson et al., 2005; Rimmel et al., 2009; Slack \& Munz, 2016).

\section{Human capital disclosure measurement}

Human capital disclosure measuring disclosed information about the implementation of key HR practices (Adams et al., 2013; Cassim \& Madlela, 2017; Kim \& Taylor, 2011; Motokawa, 2015; O’Donnell et al., 2012; Sürdü et al., 2020) generated an overall reliability of 0.806 Cronbach's alpha coefficient consistent with 0.60 (Urquiza et al., 2009) and 0.70 (Biscotti \& D'Amico, 2016; Milne \& Adler, 1999) baselines. Item reliabilities ranged between 0.777 and 0.817 confirming that these measures assessed the same underlying construct.

Similar to the SCD construct, no cases of factor loadings were detected in HCD, which also confirmed that this scale measured the underlying factors of human resource planning and recruitment, remuneration, benefits and performance as well as training and development.

\section{Relational capital disclosure measurement}

Relational capital disclosure yielded 0.749 Cronbach's alpha and the item reliabilities ranged between 0.709 and 0.737 . Cronbach's alphas above 0.70 are acceptable for this construct (Biscotti \& D'Amico, 2016; Martini et al., 2016; Milne \& Adler, 1999). There were two cases of logical inconsistencies in the way the RCD dimension was constructed which led to factor loadings. Only two items, namely customer needs and customer retention loaded on Factor 2, with loadings of 0.722 and 0.342 , respectively. These items also cross-loaded on Factor 1, at 0.382 and 0.124 . The rule of thumb is to retain a factor loading of above 0.32 (Tabachnick \& Fidell, 2001). The customer needs item in both Factor 1 and Factor 2 measured the same construct, which resulted in Factor 1 being retained, because of more items with higher loadings. Item cross-loadings can be assigned to the factor with the highest loadings (Anagnostopoulos et al., 2013). Therefore, Factor 2 remained with one item only, customer retention, which loaded the highest, compared to Factor 1. Despite the factor loadings, and overall, the items scored across the scale confirmed the presence of IC disclosure in the annual reports which measure information related to customer service, distribution channels and stakeholder partnerships (Abhayawansa \& Guthrie, 2016; Orens et al., 2009; Tejedo-Romero et al., 2017).

\section{Practical implications}

The study provides evidence that ICD can be assessed from the annual reports by means of a measurement scale to understand corporate decision-making in SC, HC and RC during the preceding financial reporting period. Whilst the preparers of the annual reports seem to focus attention on disclosing IC information, the measurement scale can facilitate this process effectively by enabling them to broadly assess different patterns of disclosure using a 7-point scoring system (see the response scale) than merely identifying the presence of information through a 0 (not disclosed) and 1 (disclosed) score which might be restrictive in limiting the extent of ICD.

Therefore, the scale applied in the study provides a framework for assessing ICD and serves as a proxy for the extent of information supplied in the capital market. Intellectual capital disclosure remains the only source of information through 
which investors can estimate how the company will generate future returns. Conversely, the lack of transparency in IC increases information asymmetry and prevents the market participants an opportunity to gain in-depth insight on how SC, HC and RC in the organisation are leveraged for creating shareholder value. Lastly, the measurement scale can be used to evaluate the extent of integrated reporting (IR) of the public listed companies.

\section{Limitations}

The limitations of the study are summarised as follows:

1. The scale exhibits predictive validity where financial performance could be predicted, and discriminant validity in that could discriminate between high and low performing companies.

2. The measurement scale is inherently subjective and only based on the researcher's scale construction. The results mostly yielded information disclosed qualitatively with less emphasis.

3. The scale was only used to examine the presence of predefined items (un-weighted scoring) in the annual reports and not the quality thereof (weighted).

4. The cross-sectional nature of the study restricted the researchers from assessing the pattern of disclosures over a period of time, which could have been achieved through a longitudinal study.

Notwithstanding these limitations, the main objective of the study, namely, 'to develop a measurement scale for evaluating the extent of ICD in the annual reports' was achieved. The reliability statistics obtained across the ICD dimensions indicate the internal consistency of the index which can be applied for both practical and research purposes. However, the results must be generalised with careful consideration to the context of future studies.

\section{Recommendations and suggestions for future research}

It is recommended that the construction of a disclosure index to score the presence of the IC information in the annual reports be based on a thorough literature survey which will guide the researcher's scale definition and item selection. Validity tests must also be conducted to increase the constructs being measured. As indicated, a longitudinal study can be carried out for validating the construction of the measurement scale by assessing changes in the pattern of disclosure.

\section{Concluding summary}

The main aim of constructing a multi-dimensional measurement scale for assessing ICD in the annual reports was achieved through EFA using a disclosure index containing 75 items categorised according to SCD (32 items), HCD (18 items) and RCD (25 items). Although, only two cases on factor loadings were detected in the RCD dimension which was later moderately restructured. The proposed measurements, therefore, add theoretical understanding of ICD. Therefore, the study provides a novel contribution to ICD by constructing a measurement scale that can be used to assess SCD, HCD and $\mathrm{RCD}$ in the annual reports/integrated reports.

\section{Acknowledgements Competing interests}

The authors have declared that no competing interests exist.

\section{Authors' contributions}

M.D.M. was responsible for the actual research under the supervision of G.R. and G.v.Z.

\section{Funding information}

This research received no specific grant from any funding agency in the public, commercial, or not-for-profit sectors.

\section{Data availability}

Secondary data were sourced from the annual or integrated reports of the companies listed in the JSE.

\section{Disclaimer}

The views and opinions expressed in this article are those of the authors and do not necessarily reflect the official policy or position of any affiliated agency of the authors, and the publisher.

\section{References}

Abdolmohammadi, M.J. (2005). Intellectual capital disclosure and market capitalisation. Journal of Intellectual Capital, 6(3), 397-416. https://doi. org/10.1108/14691930510611139

Abeysekera, I. (2006). The project of intellectual capital disclosure: Researching the research. Journal of Intellectual Capital, 7(1), 61-77. https://doi. org/10.1108/14691930610639778

Abeysekera, I. (2010). The influence of board size on intellectual capital disclosure by Kenyan listed firms. Journal of Intellectual Capital, 11(4), 504-518. https://doi. org/10.1108/14691931011085650

Abhayawansa, S., \& Guthrie, J. (2010). Intellectual capital and the capital market: A review and synthesis. Journal of Human Resource Costing \& Accounting, 14(3), 196-226. https://doi.org/10.1108/14013381011095472

Abhayawansa, S., \& Guthrie, J. (2014). Importance of intellectual capital information: A study of Australian analyst reports. Australian Accounting Review, 68(34), 6683. https://doi.org/10.1111/auar.12012

Abhayawansa, S., \& Guthrie, J. (2016). Drivers and semantic properties of intellectual capital information in sell-side analysts' reports. Journal of Accounting \& Organisational Change, 12(4), 434-471. https://doi.org/10.1108/JAOC-05-20140027

Adams, C., Coulson, A.B., Emmelkamp, T., Greveling, R., Klüth, G., \& Nugent, M. (2013). Capitals: Background paper for IR. International Integrated Reporting Council. ISSN: 2052-1723. Retrieved from https://integratedreporting.org/wpcontent/uploads/2013/03/IR-Background-Paper-Capitals.pdf

Alfraih, M.M. (2018). Intellectual capital reporting and its relation to market and financial performance. International Journal of Ethics and Systems, 34(3), 266281. https://doi.org/10.1108/IJOES-02-2017-0034

An, Y., \& Davey, H. (2010). Intellectual capital disclosure in Chinese (mainland) companies. Journal of Intellectual Capital, 11(3), 326-347. https://doi. org/10.1108/14691931011064572

Anagnostopoulos, F., Yfantopoulos, J., Moustaki, I., \& Niakas, D. (2013). Psychometric and factor analytic evaluation of the 15D health-related quality of life instrument: The case of Greece. Quality of Life Research, 22(8), 1973-1986. https:// doi.10.1007/s11136-013-0348-2

Anifowose, M., Rashid, H.M.A., \& Annuar, H.A. (2017). Intellectual capital disclosure and corporate market value: Does board diversity matter? Journal of Accounting in Emerging Economies, 7(3), 369-398. https://doi.org/10.1108/JAEE-06-20150048 
Atkins, J., \& Maroun, W. (2015). Integrated reporting in South Africa in 2012 Perspectives from South African institutional investors. Meditari Accountancy Research, 23(2), 197-221. https://doi.org/10.1108/MEDAR-07-2014-0047

Arvidsson, S. (2011). Disclosure of non-financial information in the annual report: A management-team perspective. Journal of Intellectual Capital, 12(2), 277-300. https://doi.org/10.1108/14691931111123421

Bartholomew, D., Knott, K., \& Moustaki, I. (2011). Latent variable models and factor analysis: A unified approach (3rd ed.). London: Wiley. https:// doi.10.1002/9781119970583.

Bartlett, F.C. (1950). Incentives. British Journal of Psychology, 41(3-4), 122-128. https://doi.org/10.1111/j.2044-8295.1950.tb00270.x

Bini, L., Dainelli, F., \& Giunta, F. (2016). Business model disclosure in the strategic report: Entangling intellectual capital in value creation process. Journal of Intellectual Capital, 17(1), 83-102. https://doi.org/10.1108/JIC-09-2015-0076

Biscotti, A.M., \& D'Amico, E. (2016). Theoretical foundation of IC disclosure strategies in high-tech industries. International Journal of Disclosure and Governance, 13(1) 1-25. https://doi.org/10.1057/jdg.2015.8

Bornmann, L., \& Daniel, H.D. (2008). What do citation counts measure? A review of studies on citing behaviour. Journal of Documentation, 64(1), 45-80. https://doi. org/10.1108/00220410810844150

Bowrin, A.R. (2018). Human resources disclosures by African and Caribbean companies. Journal of Accounting in Emerging Economies, 8(2), 244-278. https:// doi.org/10.1108/JAEE-07-2016-0065

Bozzolan, S., Favotto, F., \& Ricceri, F. (2003). Italian annual intellectual capital disclosure: An empirical analysis. Journal of Intellectual Capital, 4(4), 543-558. https://doi.org/10.1108/14691930310504554

Bukh, P.N., Nielsen, C., Gormsen, P., \& Mouritsen, J. (2005). Disclosure of information on intellectual capital in Danish IPO prospectuses. Accounting, Auditing \& Accountability Journal, 18(6), 713-732. https://doi.org/10.1108/09513570510627685

Cardi, C., Mazzoli, C., \& Severini, S. (2019). People have the power: Post IPO effects of intellectual capital disclosure. Journal of Economics \& Finance, 43, 228-255. https://doi.org/10.1007/s12197-018-9439-9

Cassim, R., \& Madlela, V. (2017). Disclosure of directors' remuneration under South African Company Law: Is it adequate? (2017) 1349(2) SALJ 383-414. South African Law Journal, 34(2), 383-414.

Cheung, Y.L., Jiang, P., \& Tan, W. (2010). A transparency disclosure index measuring disclosures: Chinese listed companies. Journal of Accounting and Public Policy, 29(3), 259-280. https://doi.org/10.1016/j.jaccpubpol.2010.02.001

Chen, M.C., Cheng, S.J., \& Hwang, Y. (2005). An empirical investigation of the relationship between intellectual capital and firms' market value and financial performance. Journal of Intellectual Capital, 6(2), 159-176. https://doi. org/10.1108/14691930510592771

Chiucchi, M.S., \& Dumay, J. (2015). Unlocking intellectual capital. Journal of Intellectual Capital, 16(2), 305-330. https://doi.org/10.1108/JIC-01-2015-0004

Child, D. (2006). The essentials of factor analysis (3rd ed.). New York, NY: Continuum International Publishing Group.

Coy, D.V. (1995). A public accountability index for annual reporting by NZ universities (Doctoral thesis). Hamilton: University of Waikato.

Dammak, S., Triki, M., \& Boujelbene, Y. (2010). Towards a measurement scale for the voluntary disclosure of the intellectual capital. Journal of Advanced Research in Management, 1(1), 30-44.

Devalle, A., Rizzato, F., \& Busso, D. (2016). Disclosure indexes and compliance with mandatory disclosure - The case of intangible assets in the Italian market. Advances in Accounting, 35, 8-25. https://doi.org/10.1016/j.adiac.2016.04.003

Dominguez, A.A. (2011). The impact of human resource disclosure on corporate image. Journal of Human Resource Costing \& Accounting, 15(4), 279-298. https:// doi.org/10.1108/14013381111197225

Edgar, V.C., Beck, M., \& Brennan, N.M. (2018). Impression management in annual report narratives: The case of the UK private finance initiative. Accounting Auditing \& Accountability Journal, 31(2), 1566-1592. https://doi.org/10.1108/ AAAJ-10-2016-2733

Gamerschlag, R. (2013). Value relevance of human capital information. Journal of Intellectual Capital, 14(2), 325-345. https://doi.org/10.1108/14691931311323913

García-meca, E., Parra, I., Larrán, M., \& Martínez, I. (2005). The explanatory factors of intellectual capital disclosure to financial analysts. European Accounting Review, 14(1), 63-94. https://doi.org/10.1080/0963818042000279713

Gerpott, T.J., Thomas, S.E., \& Hoffmann, A.P. (2008). Intangible asset disclosure in the telecommunications industry. Journal of Intellectual Capital, 9(1), 37-61. https:// doi.org/10.1108/14691930810845795

Guthrie, J., Petty, R., \& Ricceri, F. (2006). The voluntary reporting of intellectual capital: Comparing evidence from Hong Kong and Australia. Journal of Intellectual Capital, 7(2), 254-271. https://doi.org/10.1108/14691930610661890

Hooks, J., Coy, D., \& Davey, H. (2001). The annual reports of New Zealand electricity companies: Assessing quality. Pacific Accounting Review, 13(2), 35-69. https:// doi.org/10.1108/eb037960

Hosseini, M., \& Owlia, M.S. (2016). Designing a model for measuring and analyzing the relational capital using factor analysis: Case study, Ansar Bank. Journal of Intellectual Capital, 17(4), 734-757. https://doi.org/10.1108/JIC-04-2016-0042

Huang, C.C., Luther, R., Tayles, M., \& Haniffa, R. (2013). Human capital disclosures in developing countries: Figureheads and value creators. Journal of Applied Accounting Research, 14(2), 180-196. https://doi.org/10.1108/09675421311291919
Hurley, A.E., Scandura, T.A., Schriesheim, C.A., Brannick, M.T., Seers, A., Vandenberg, R.J., \& Williams, L.J. (1997). Exploratory and confirmatory factor analysis: Guidelines, issues, and alternatives. Journal of Organizational Behaviour, 18(6), 667-683. https://doi.org/10.1002/(SICI)1099-1379(199711)18:6<667::AID-JOB874>3.0.CO;2-T

Husin, N.M., Hooper, K., \& Olesen, K. (2012). Analysis of intellectual capital disclosure - An illustrative example. Journal of Intellectual Capital, 13(2), 196-220. https:// doi.org/10.1108/14691931211225030

Kaiser, H.F. (1961). A note on Guttman's lower bound for the number of common factors. British Journal of Statistical Psychology, 14, 1-2. https://doi. org/10.1111/j.2044-8317.1961.tb00061.x

Kaiser, H.F. (1974). An index of factorial simplicity. Psychometrika, 39(1), 31-36. https://doi.org/10.1007/BF02291575

Kale, P., Singh, H., \& Perlmutter, H. (2000). Learning and protection of proprietary assets in strategic alliances: Building relational capital. Strategic Management Journa 21(3), 217-237. https://doi.org/10.1002/(SICI)1097-0266(200003)21:3<217::AIDSMJ95>3.0.CO;2-Y

Kannan, G., \& Aulbur, W.G. (2004). Intellectual capital: Measurement effectiveness. Journal of Intellectual Capital, 5(3), 389-413. https://doi.org/10.1108/ 14691930410550363

Karanges, E., Johnston, K., Beatson, A., \& Lings, I. (2015). The influence of interna communication on employee engagement: A pilot study. Public Relations Review, 41(1), 129-131. https://doi.org/10.1016/j.pubrev.2014.12.003

Kim, S.H., \& Taylor, D. (2011). Labour cost disclosures: Have IFRSs made a difference? Journal of Human Resource Costing \& Accounting, 15(2), 127-146. https://doi. org/10.1108/14013381111157346

Krippendorff, K. (2013). Content analysis. An introduction to its methodology (3rd ed.). California, CA: Sage Publications.

Kleinheksel, A.J., \& Ritzhaupt, A.D. (2017). Measuring the adoption and integration of virtual patient simulations in nursing education: An exploratory factor analysis. Computers \& Education, 108, 11-29. https://doi.org/10.1016/j.compedu.2017.01.005

Larsen, R., \& Warne, R.T. (2010). Estimating confidence intervals for eigenvalues in exploratory factor analysis. Behaviour Research Methods, 42(3), 871-876. https:// doi.org/10.3758/BRM.42.3.871

Lenciu, N.M., \& Matis, D. (2014). Inflection points in the development of IAS 38. Journal of Financial Reporting and Accounting, 12(1), 62-75. https://doi. org/10.1108/JFRA-04-2012-0014

Litschka, M., Markom, A., \& Schunder, S. (2006). Measuring and analysing intellectual assets: An integrative approach. Journal of Intellectual Capital, 7(2), 160-173. https://doi.org/10.1108/14691930610661836

Magau, M.D., Roodt, G., \& Van Zyl, G. (2021). Monetary value of human capital disclosure for predicting future business earnings. SA Journal of Human Resource Management/SA Tydskrif vir Menslikehulpbronbestuur, 19(0), a1398. https://doi. org/10.4102/sajhrm. v19i0.1398

Martini, S.B., Corvino, A., Doni, F., \& Rigolini, A. (2016). Relational capital disclosure, corporate reporting and company performance: Evidence from Europe. Journal of Intellectual Capital, 17(2), 186-217. https://doi.org/10.1108/JIC-07-2015-0065

Milne, M.J., \& Adler, R.W. (1999). Exploring the reliability of social and environmental disclosures content analysis. Accounting, Auditing \& Accountability Journal, 12(2), 237-256. https://doi.org/10.1108/09513579910270138

Motokawa, K. (2015). Human capital disclosure, accounting numbers, and share price. Journal of Financial Reporting \& Accounting, 13(2), 159-178. https://doi. org/10.1108/JFRA-11-2014-0089

Mulaik, S.A. (2009). Foundations of factor analysis (2nd ed.). New York: Chapman and Hall/CRC.

Neves, M.F., Zuurbier, P., \& Campomar, M.C. (2001). A model for the distribution channels planning process. Journal of Business \& Industrial Marketing, 16(7), 518-539. https://doi.org/10.1108/08858620110408757

Nielsen, C., Rimmel, G., \& Yosano, T. (2015). Outperforming markets: IC and the longterm performance of Japanese IPOs. Accounting Forum, 39(2), 83-96. https://doi. org/10.1016/j.accfor.2015.04.001

O’Donnell, L., Kramar, R., \& Dyball, M.C. (2012). Human capital reporting: Should it be industry specific? Asian Pacific Journal of Human Resources, 47(3), 358-373. https://doi.org/10.1177/1038411108099293

Oliveira, L., Rodrigues, L., \& Craig, R. (2006). Firm-specific determinants of intangibles reporting: Evidence from the Portuguese stock market. Journal of Human Resource Costing and Accounting, 10(1),11-33. https://doi.org/10.1108/14013380610672657

Olson, E.M., Slater, S.F., \& Hult, G.T.M. (2005). The performance implications of fit among business strategy, marketing organisation structure, and strategic behaviour. Journal of Marketing, 69(3), 49-65. https://doi.org/10.1509/jmkg.69.3.49.66362

Orens, R., Aerts, W., \& Lybaert, N. (2009). Intellectual capital disclosure, cost of finance and firm value. Management Decision, 47(10), 1536-1554. https://doi. org/10.1108/00251740911004673

Park, S., Lee, H., \& Chae, S.W. (2017). Rethinking balanced scorecard (BSC) measures: Formative versus reflective measurement models. International Journal of Productivity and Performance Management, 66(1), 92-110. https://doi.org/10.1108/ IJPPM-08-2015-0109

Pather, S., \& Uys, C.S. (2008). Using scale reduction techniques for improved quality of survey information. SA Journal of Information Management, 10(3), 1-14. https:// doi.org/10.4102/sajim.v10i3.322

Petty, R., \& Guthrie, J. (2000). Intellectual capital literature review: Measurement, reporting and management. Journal of Intellectual Capital, 1(2), 155-176. https:// doi.org/10.1108/14691930010348731 
Piehler, R., King, C., Burmann, C., \& Xiong, L. (2016). The importance of employee brand understanding, brand identification, and brand commitment in realising brand citizenship behaviour. European Journal of Marketing, 50(9/10), 15751601. https://doi.org/10.1108/EJM-11-2014-0725

Rimmel, G., Nielsen, C., \& Yosano, T. (2009). Intellectual capital disclosures in Japanese IPO prospectuses. Journal of Human Resource Costing \& Accounting, 13(4), 316 337. https://doi.org/10.1108/14013381011010150

Schepers, J.M. (1992). Toetskonstruksie: Teorie en praktyk. Johannesburg: RAU Drukpers.

Schneider, A., \& Samkin, G. (2008). Intellectual capital reporting by the New Zealand local government sector. Journal of Intellectual Capital, 9(3), 456-486. https://doi. org/10.1108/14691930810892036

Setia, N., Abhayawansa, S., Joshi, M., \& Vu Huynh, A. (2015). Integrated reporting in South Africa: Some initial evidence. Sustainability Accounting, Management and Policy Journal, 6(3), 397-424. https://doi.org/10.1108/SAMPJ-03-2014-0018

Singh, S., \& Kansal, M. (2011). Voluntary disclosures of intellectual capital: An empirical analysis. Journal of Intellectual Capital, 12(2), 301-318. https://doi. org/10.1108/14691931111123430

Slack, R., \& Munz, M. (2016). Intellectual capital reporting, leadership and strategic change. Journal of Applied Accounting Research, 17(1), 61-83. https://doi org/10.1108/JAAR-02-2014-0021

Sonnier, B.M. (2008). Intellectual capital disclosure: High-tech versus traditiona sector companies. Journal of Intellectual Capital, 9(4), 705-722. https://doi. org/10.1108/14691930810913230

Striukova, L., Unerman, J., \& Guthrie, J. (2008). Corporate reporting of intellectua capital: Evidence from UK companies. British Accounting Review, 4O(4), 297-313. https://doi.10.1016/j.bar.2008.06.001
Sürdü, F.B., Çalıskan, A.Ö., \& Esen, E. (2020). Human resource disclosures in corporate annual reports of insurance companies: A case of developing country. Sustainability, 12(8), 1-21. https://doi:10.3390/su12083452

Suri, H. (2008). Ethical considerations in synthesising research - Whose representations? Qualitative Research Journal, 8(1), 63-73. https://doi.org/10.3316/QRJ0801062

Tabachnick, B.G., \& Fidell, L.S. (2001). Using multivariate statistics. Boston, MA: Allyn and Bacon.

Tejedo-Romero, F., Rodrigues, L.L., \& Craig, R. (2017). Women directors and disclosure of intellectual capital information. European Research on Management and Business Economics, 23(3), 123-131. https://doi.org/10.1016/j.iedeen.2017.06.003

Thomas, A. (2012). Governance at South African state-owned enterprises: What do annual reports and the print media tell us? Social Responsibility Journal, 8(4), 448-470. https://doi.org/10.1108/17471111211272057

Urquiza, F.B., Navarro, M.C.A., \& Trombetta, M. (2009). Disclosure indices design: Does it make a difference? Revista de Contabilidad, 12(2), 253-277. https://doi. org/10.1016/S1138-4891(09)70008-1

Vandemaele, S.N., Vergauwen, P.G.M.C., \& Smits, A.J. (2005). Intellectual capital disclosure in The Netherlands, Sweden and the UK: A longitudinal and comparative study. Journa of Intellectual Capital, 6(3), 417-426. https://doi.org/10.1108/14691930510611148

Vergauwen, P., Bollen, L., \& Oirbans, E. (2007). Intellectual capital disclosure and intangible value drivers: An empirical study. Management Decision, 45(7), 11631180. https://doi.org/10.1108/00251740710773961

Wagiciengo, M.M., \& Belal, A.R. (2012). Intellectual capital disclosures by South African companies: A longitudinal investigation. Advances in Accounting, 28(1) 111-119. https://doi.org/10.1016/j.adiac.2012.03.004

Whiting, R.H., \& Miller, J.C. (2008). Voluntary disclosure of intellectual capital in New Zealand annual reports and the hidden value. Journal of Human Resource Costing \& Accounting, 12(1), 26-50. https://doi.org/10.1108/14013380810872725 